\title{
CDISC SDTM Trial Type Terminology
}

National Cancer Institute

\section{Source}

National Cancer Institute. CDISC SDTM Trial Type Terminology. NCI Thesaurus. Code C66739.

Terminology codelist used with Trial Type within the Clinical Data Interchange Standards Consortium Study Data Tabulation Model. 